\title{
An Alternative Method for Percutaneous Treatment Of Hydatid Cysts: PAI Technique
}

\section{Hidatik Kistin Perkütan Tedavisinde Alternatif Metod: PAI Tekniği}

\section{Burhan Özdil', Can Keçe², Ömer Vedat Ünalp³}

${ }^{1}$ Clinic of Gastroenterelogy, Private Adana Hospital, Adana, Turkey

${ }^{2}$ Clinic of Gastroenterological Surgery, Numune Training and Research Hospital, Trabzon, Turkey

${ }^{3} \mathrm{Clinic}$ of General Surgery, Arhavi State Hospital, Artvin, Turkey

\section{ABSTRACT}

Objective: Surgery is still the first choice in complicated cystic echinococcosis. However, percutaneous methods have performed increasingly in recent years. The Puncture, Aspiration, Injection, Reaspiration (PAIR) technique is mostly the preferred percutaneous method. The Puncture, Aspiration, Injection (PAI) technique is the new modified method, which is differentiated from PAIR technique by its applicability to all types of hydatid cysts (types 1-5) and unperforming of reaspiration.

Methods: The 52 hydatid cysts were prospectively examined in the study. Thirty-four of them were Types I and II, 13 of them were Type III, and 5 of them were Types IV and V. The technique was performed using the $20 \mathrm{G}$ Chiba needle under the guidance of ultrasonography. Maximum cyst contents were aspirated immediately after the puncture to reduce the intracystic pressure. After confirming that aspirated liquid does not contain bile and that cyst has no cystobiliary connection, $95 \%$ alcohol was injected into the cavity, safely. Reaspiration of alcohol was not performed.

Results: The cyst sizes were reduced after PAI on ultrasonographic evaluations in all cases. The liquid component disappeared and the cyst got solid characteristic three months after the procedure.

Conclusion: All hydatid cyst types can be treated safely and effectively with PAI technique without considering dimensions and whether.

Keywords: Cyst hydatid, therapeutic, methods

Received: 26.04 .2015

Accepted: 14.04 .2016

\section{ÖZ}

Amaç: Cerrahi komplike kistik ekinokokkoziste hala ilk seçenektir. Buna ragmen son yıllarda perkütan metodlar daha sık uygulanmaktadır. PAIR (Giriş, Aspirasyon, İnjeksiyon, Reaspirasyon) tekniği çok sık uygulanan bir metodtur. PAl tekniği (Giriş, aspirasyon, İnjeksiyon) reaspirasyonun yapılmadığı ve tüm kist tiplerine (tip1-5) uygulanabilen yeni bir metodtur.

Yöntemler: Prospektif olarak 52 hidatik kist olgusu çalışmaya alındı. Bunlardan 34'ü tip I-II, 13 tanesi tip III, 5 tanesi de tip IV ve V idi. Teknik ultrasonografi eşliğinde $20 \mathrm{G}$ chiba ignesi kullanılarak yapıldı. Kist içine girer girmez kist basıncını düşürmek için maksimum içerik aspire edildi. Aspire edilen sıvıda bilier bağlantıyı gösteren safra sızıntısı olmadığından emin olduktan sonra kist kavitesi içine \% 95 alkol verildi. Reaspirasyon yapılmadı.

Bulgular: Üç ay sonraki ultrasonografik değerlendirmede tüm vakalarda kist boyutu küçüldü. Kistin likit komponenti kayboldu ve solit karakter kazandı.

Sonuç: İçerisinde kız vezikül, yoğun septasyon varlığı ve kist boyutuna bakılmaksızın tüm hidatik kistler PAl tekniği ile güvenli ve etkili bir şekilde tedavi edilebilir.

Anahtar Kelimeler: Kist hidatik, teropatik, metodlar.

Geliş Tarihi: 26.04.2015

Kabul Tarihi: 14.04 .2016

Address for Correspondence / Yazışma Adresi: Burhan Özdil E.mail: burhanozdil@gmail.com DOI: 10.5152/tpd.2016.4264

CCopyright 2016 Turkish Society for Parasitology - Available online at www.tparazitolderg.org

OTelif hakkı 2016 Türkiye Parazitoloji Derneği - Makale metnine www.tparazitolderg.org web sayfasından ulaşılabilir. 

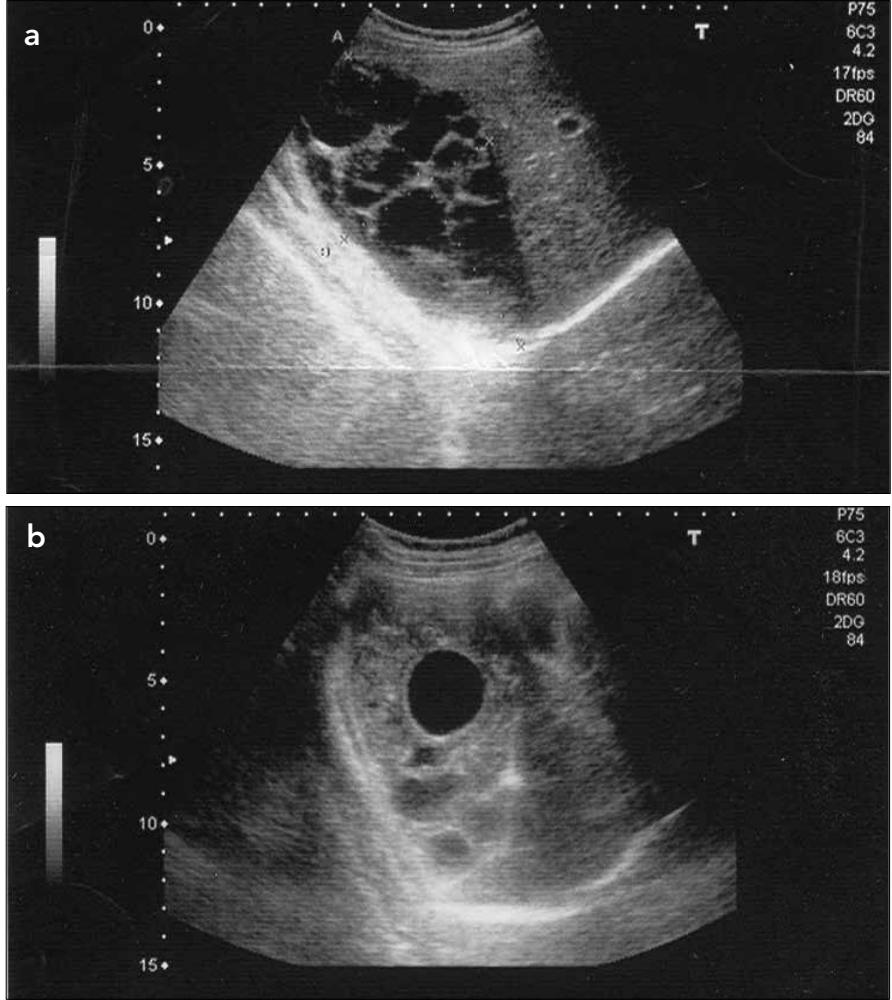

Figure 1. a, b. 21 aged female patients, Type III hydatid cyst localized at liver right lobe and neighborhood of right surrenal. A. Before treatment, B. Appearance 4 months after treatment

\section{INTRODUCTION}

Cystic echinococcosis is a zoonotic disease caused by Echinococcus granulosus. Its involvement shows a distribution of $60 \%$ in the liver, $20 \%$ in the lungs, and $20 \%$ in the other various organs. They have an annual growth as 1-30 $\mathrm{mm}$ in diameter and may contain daughter vesicles. The organism envelops the cyst to limit the disease. However, the cyst can continue growing and maintain its activity (1). Mostly they are asymptomatic and are coincidentally diagnosed. They may be presented with mild abdominal pain, infection, bile duct compression, peritonitis, and pneumonia. Occasionally, sever anaphylactic reactions might be observed due to spontaneous or traumatic ruptures $(2,3)$. Currently, surgery is the first therapeutic choice in complicated cases; however, in recent years percutaneous methods have become increasingly important. The most commonly used method for percutaneous drainage is the Puncture, Aspiration, Injection, Reaspiration (PAIR) technique (4). However, this method has some limitations; it shows efficacy primarily on cysts of Type I and II. The Puncture, Aspiration, Injection (PAI) technique is the method that we apply in this study, which is differentiated from the PAIR technique by unperforming of reaspiration. The results of 25 cases that were treated by the PAI technique are presented in this study.

\section{METHODS}

Twenty-five patients with hydatid cysts, who were admitted to the Gastroenterology Clinic, were included in this study. Of the 25 cases, 18 (72\%) were female and 7 (28\%) were male. Hydatid cysts were diagnosed and confirmed by ultrasonography (USG)
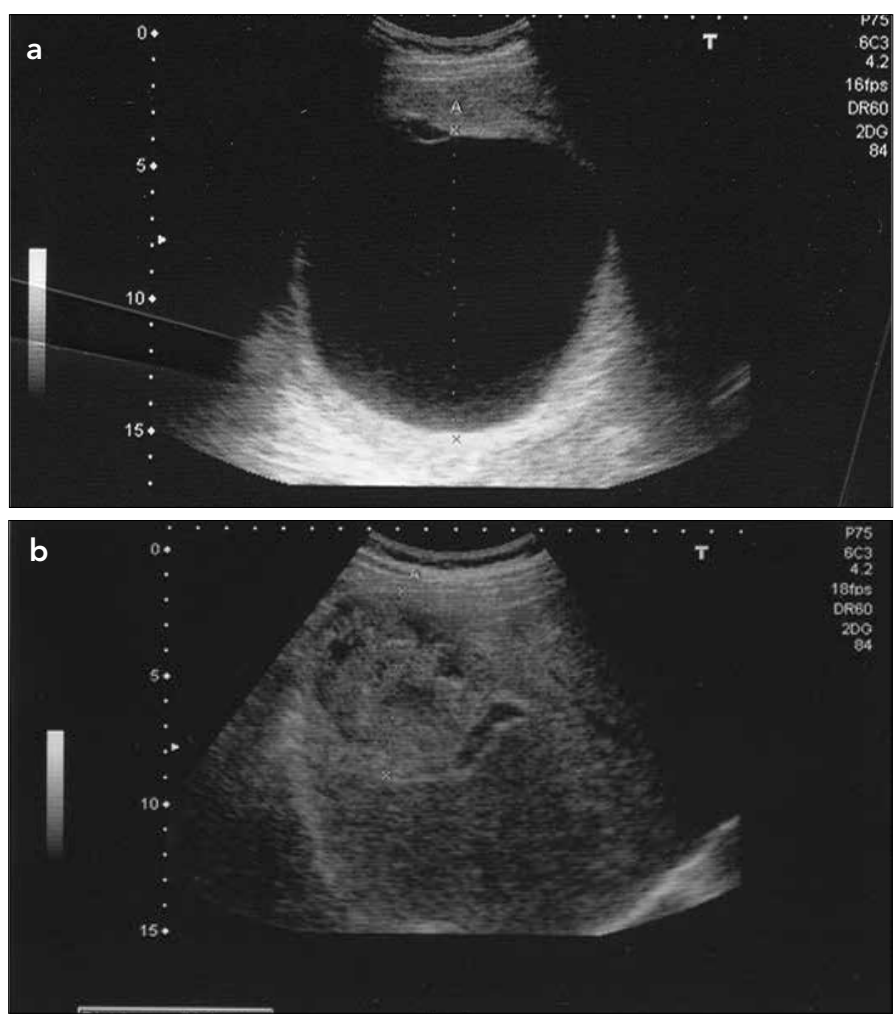

Figure 2. a, b. Hydatid cyst of $120 \mathrm{~mm}$ in diameter before treatment (a), Appearance 7 months after treatment (b). The cystic lesion reduced in size and became solid

and tomography. All cysts were located in the liver in all patients. The indirect hemaglutination (IHA) tests were high in all patients. Total number of cysts was 52. Informed consents of all patients were received. An approval was obtained for this study from the local ethics committee (2010/188). Out of 52 cysts, 34 were Type I and II, 13 were Type III, and 5 were Type IV and V (5). Before the procedure, all patients underwent albendazole treatment with a dose of $10 \mathrm{mg} / \mathrm{kg}$ for 4 weeks. Sedo-analgesia was performed with $4 \mathrm{mg}$ midazolame before the procedure. Cysts were punctured at the first attempt with the guidance of USG using $20 \mathrm{G}$ Chiba needle. Maximum cyst contents were aspirated immediately after the puncture to reduce the intracystic pressure. After confirming that the aspirated liquid did not include bile and the cyst had no cystobiliary connection, $95 \%$ alcohol in half amount of initially aspirated liquid was injected into the cavity, safely. Reaspiration of alcohol was not performed. Next, 1cc of alcohol was injected into the needle tracts to avoid causing any seeding through the needle tract. Following the procedure, albendazole treatment was continued for 1 month. Just after the procedure, prophylactic ciprofloxacin treatment was administered with a dose of $2 \times 500 \mathrm{mg} /$ day. Prophylactic antibiotic administration was performed to prevent secondary bacterial contamination. The PAI method was especially convenient for cases with Type I and II cysts. The content of Type III cysts could not be completely aspirated because of the daughter vesicles. In these cases, daughter vesicles were aspirated as much as possible and same amount of alcohol was injected into the cavity before withdrawing the needle from the main cyst. In some cases, having many daughter vesicles and septations required a second procedure. In Type IV and V cysts, alcohol was in- 
Table 1. The biochemical measurements and USG follow-up of the patients before and during 1 year after the treatment

\begin{tabular}{|c|c|c|c|c|c|c|c|}
\hline & Before & & & After treatment & & & \\
\hline & treatment & $10^{\text {th }}$ day & $1^{\text {st }}$ month & $3^{\text {rd }}$ month & $6^{\text {th }}$ month & $12^{\text {th }}$ month & $p$ \\
\hline Cyst diameter/mm & $61,5 \pm 35$ & & & $45 \pm 18$ & $36 \pm 15$ & $35 \pm 17$ & 0.003 \\
\hline Cyst hydatid IHA titre & $1280 \pm 835$ & & & $1960 \pm 480$ & $640 \pm 572$ & $180 \pm 95$ & 0.002 \\
\hline AST U/L & $21.7 \pm 6.8$ & $18.9 \pm 7.5$ & $20.1 \pm 6.5$ & $19.8 \pm 8.4$ & $20.3 \pm 7.5$ & $24.4 \pm 8.9$ & NS \\
\hline ALT U/L & $26.5 \pm 5.0$ & $25.5 \pm 10.5$ & $19.2 \pm 8.6$ & $21.2 \pm 6.7$ & $22.7 \pm 9.8$ & $22.6 \pm 10.1$ & NS \\
\hline GGT U/L & $38.7 \pm 20.5$ & $34.4 \pm 16.7$ & $33.8 \pm 18.2$ & $39.1 \pm 11.5$ & $32.8 \pm 15.6$ & $36.4 \pm 9.7$ & NS \\
\hline ALP U/L & $208.4 \pm 88.7$ & $197.9 \pm 91.4$ & $207.5 \pm 69.2$ & $186.6 \pm 101.3$ & $211.6 \pm 68.6$ & $212 \pm 79$ & NS \\
\hline T bil mg/dL & $0.6 \pm 0.2$ & $0.5 \pm 0.2$ & $0.8 \pm 0.1$ & $0.4 \pm 0.1$ & $0.7 \pm 0.3$ & $0.6 \pm 0.1$ & NS \\
\hline $\mathrm{D}$ bil mg/dL & $0.1 \pm 0.1$ & $0.2 \pm 0.1$ & $0.1 \pm 0.1$ & $0.1 \pm 0.1$ & $0.2 \pm 0.1$ & $0.1 \pm 0.1$ & NS \\
\hline $\mathrm{WBC} / \mathrm{mm}^{3}$ & $7925 \pm 2384$ & $8337 \pm 2427$ & $6458 \pm 1438$ & $8698 \pm 1242$ & $6577 \pm 1027$ & $7650 \pm 1280$ & NS \\
\hline CRP & $15.6 \pm 15.4$ & $12.5 \pm 10.0$ & $15.5 \pm 5.0$ & $8.5 \pm 6.1$ & $7.5 \pm 4.8$ & $9.7 \pm 3.2$ & NS \\
\hline
\end{tabular}

AST: aspartate transaminase; ALT: alanine transaminase; ALP: alkaline phosphatase; GGT: gamma-glutamyltransferase; T bil: total bilirubin; D bil: direct bilirubin; CRP: c-reactive protein; WBC: white blood count; IHA: indirect hemaglutination

Table 2. Similarities and differences of the two techniques of PAI and PAIR

\begin{tabular}{|c|c|c|}
\hline & PAI & PAIR \\
\hline \multirow[t]{4}{*}{ Type of the process } & Puncture: Entrance to the cyst & Puncture: Entrance to the cyst \\
\hline & Aspiration: Aspiration of the cyst contains & Aspiration: Aspiration of the cyst contains \\
\hline & $\begin{array}{l}\text { Injection: The injection of the } \\
\text { scolicidal agent (alcohol) }\end{array}$ & $\begin{array}{l}\text { Injection: The injection of the } \\
\text { scolicidal agent (alcohol, } \\
\text { hypertonic NaCL solution) }\end{array}$ \\
\hline & & $\begin{array}{l}\text { Reabsorbtion: The reabsorbtion of the } \\
\text { scolicidal agent (after 20-30 min waiting period) }\end{array}$ \\
\hline $\begin{array}{l}\text { Which type of cysts can this } \\
\text { technique be applied to }\end{array}$ & $\begin{array}{l}\text { Very good for Type I, II, and } \\
\text { III and good for Type IV and V }\end{array}$ & Only for Type I and II \\
\hline Size of the cyst & All sizes are suitable & Smaller than $6 \mathrm{~cm}$ is suitable \\
\hline Process duration & Shorter & $\begin{array}{l}\text { Long (waiting time of } 20-30 \mathrm{~min} \\
\text { for scolicidal agent and time for reabsorbtion) }\end{array}$ \\
\hline Complication & $\begin{array}{l}\text { Pain at the needle entrance area } \\
\text { and shoulder (5\%) }\end{array}$ & $\begin{array}{c}\text { Pain at the needle entrance area } \\
\text { and shoulder (5\%) }\end{array}$ \\
\hline
\end{tabular}

jected directly into the cysts because they did not have any liquid content to be aspirated. Generally, increased intracystic pressure may cause pain. Although the amount of the injected alcohol was dependent on the cyst sizes, administered volume were the maximum amount without causing pain in patients. The patients were controlled for biochemical, radiologic, and clinical evaluations in the $1^{\text {st }}, 3^{\text {rd }}, 6^{\text {th }}$, and $12^{\text {th }}$ months. No pathology was observed in physical evaluations. They did not have any complains. Ultrasonographic measurements of the cyst diameters were evaluated in the $3^{\text {rd }}, 6^{\text {th }}$, and $12^{\text {th }}$ months.

\section{Statistical analysis}

Data analysis was performed using the computer software Statistical Package for the Social Sciences (SPSS 15.0, IBM Corporation, New York, USA). Differences in the distributions of demographic characteristics and laboratory data were evaluated using the paired-samples $t$-test (for continuous variables before and after treatment) and the one-way ANOVA test. Probability levels $<0.05$ were used as a criterion of significance.

\section{RESULTS}

The sizes of the cysts were reduced in USG measurements in all cases. Liquid components of the cysts disappeared and they had solid characteristics (Figure 1a, b, Figure 2a, b) in the control USG. Although IHA measurements markedly increased at the first control, there were progressive regression of the IHA titres at $6^{\text {th }}$ and $12^{\text {th }}$ months controls ( $p=0.002$ ) (Table 1$)$. The cases were followed-up for one year in terms of values as aspartate transaminase (AST), alanine transaminase (ALT), alkaline phosphatase (ALP), gamma-glutamyltransferase (GGT), total-direct bilirubin, C-reactive protein (CRP), and white blood counts (WBC) (Table 1). No significant difference was observed between the biochemical values of pre- and post-treatment. Some cases (5\%) had mild abdominal and shoulder pain, presumably sourced from peritoneal irritation of alcohol administrations (Table 2). They mostly lasted for an hour and rarely continued for $24 \mathrm{~h}$. No analgesic medication was required. Anaphylactic reaction secondary to the process was not observed. 


\section{DISCUSSION}

Surgery is still the most used method worldwide, but it does not have $100 \%$ efficacy on hydatid cyst treatment yet. Surgery inactivates infectious materials, prevents contamination, and treats the residual cavities $(3,6)$. Numerous traditional surgery methods have been described, such as marsupialization, external tube drainage, partial or total cystectomy, omentopexy, capitonage, and cystojejunostomies $(3,6,7)$. The surgical mortaliy rate is $3 \%$, whereas complication rates (i.e., cystic infections, bleeding, biliary fistules, sepsis, and anaphylaxis), especially in multiple cysts, ranges between 10\%-12.5\%. Mean hospital stays were 15.5 days (8). There is no accepted and uniform surgical technique, and each cyst may need different types of interventions in multiple cysts $(9,10)$.

Currently, there is a great intense to perform minimal invasive surgical techniques instead of conventional methods, but laparoscopic methods have some disadvantages such as bleeding, spreading of cyst materials, and limitation of the manipulation during process.

In recent years, interventional radiologists and gastroenterologists have begun to use the PAIR and percutaneous evacuation of cyst content techniques (11-14). Nowadays, cysts are mostly being treated using the PAIR technique in combination with USG. In the PAIR technique; half of the cyst volume is aspirated, $20 \%$ hypertonic saline solution is injected as $1 / 3^{\text {rd }}$ of the initial cyst volume. After 20 min, the cyst volume is aspirated again (4). It is merely used for Type I and II cysts below the size of $6 \mathrm{~cm}$. Additionally, it is not applicable for the cysts that are calcific and solid (15-18). The cysts in Type III and those bigger than $6 \mathrm{~cm}$ are treated with percutaneous drainage catheter administration $(4,19)$.

The cysts that are localized peripherally are estimated to be ruptured during punction. An estimated risk for anaphylactic shock due to the percutaneous drainage or spreading of cysts over peritoneal surface exists. However, entrance into the cyst passing through the liver paranchyme instead of the free edge of the cyst can reduce this risk. The frequency and mechanism of the shock is not well documented yet (20). Lewall et al. (21) have reported 20 hydatid cyst ruptures without any anaphylaxis. The risks of the PAIR technique are also similar to those of the surgery. Besides this, the PAIR technique is quite better in terms of hospital stay, mortality, and morbidity (8). Various scolicidal agents following percutaneous cyst drainage have been used. Hypertonic saline and $95 \%$ alcohol are the mostly used ones $(22,23)$.

Our method described here has similar technical properties with the original PAIR technique. Not performing the reaspiration of the injected alcohol from the cyst cavity is the main difference of the PAI technique from the PAIR technique. For this reason, we called it as the PAI technique. The waiting time of scolicidal agent is approximately 20-30 min. Because injected alcohol is not reabsorbed, PAI is also a short procedure as compared with PAIR (Table 2).

We suggest that not only the cysts in Type I and II but also all other cysts can be treated by the PAl technique. In the PAIR technique, as the alcohol is reaspirated, there is a probability of some daughter vesicles not to be exposed to injected alcohol. Especially in cysts with septations, daughter vesicles can main- tain their viability since alcohol cannot penetrate all neighbor compartments, whereas in PAI technique, alcohol is absorbed slowly so that it can completely contact and damage the germinative inner membrane of the cyst. Although the daughter vesicles are not aspirated percutaneously, alcohol penetrates the vesicle membrane easily and kills all vesicles. Injected alcohol, in cases with septation, can penetrate through the neighbor compartments and cause the death of cysts. In all cases, IHA test values increased gradually in the early period after the procedure but reduced significantly in the late period. Cysts diameters were also decreased on ultrasonographic examination. It may suggest that thick cyst wall can be destroyed immunologically. The management of the large cyst cavities is difficult and can lead to some problems after surgery (9). In the PAI technique, the cavity regression occurs progressively even in a large cavity (Figures 1, 2). The cysts with noneligible walls should be avoided to inject large amount of alcohol due to the risks of sclerosing cholangitis and damage to liver parenchyme. Our cases were followed-up for one year after the procedure to check for complications such as sclerosing cholangitis and abscess formation. No major complications was observed.

In conclusion, hydatid cysts can be treated with the PAl technique without considering whether they include size differences, septations, and daughter vesicles. The exposure to alcohol for a long time considerably increases the success of the treatment and may cause complete resolution even in large cysts (Figure $2 a, b)$. As the thickness of the cyst wall decelerates the absorbtion of the alcohol, theoretically, this procedure is free from the risk of damaging the liver paranchyme and developing sclerosing cholangitis. According to these results, PAI is a safe, easily performed, and effective treatment option for all kinds of hydatid cysts.

Ethics Committee Approval: Ethics committee approval was received for this study from the local ethics committee (2010/188).

Informed Consent: Written informed consent was obtained from patients

Peer-review: Externally peer-reviewed.

Author Contributions: Concept - B.Ö.; Design - B.Ö.; Supervision B.Ö., C.K., Ö.V.Ü.; Funding - B.Ö., C.K.; Materials - B.Ö., C.K.; Data Collection and/or Processing - B.Ö., C.K.,Ö.V.Ü.; Analysis and/or Interpretation - B.Ö., C.K., Ö.V.Ü.; Literature Review - B.Ö., C.K.; Writing - B.Ö., C.K.; Critical Review - B.Ö., C.K., Ö.V.Ü.

Conflict of Interest: No conflict of interest was declared by the authors

Financial Disclosure: The authors declared that this study has received no financial support.

Etik Komite Onayı: Bu çalışma için lokal etik komiteden onay alınmıştır.

Hasta Onamı: Yazılı hasta onamı bu çalışmaya katılan hastalardan alınmıştır.

Hakem Değerlendirmesi: Dış bağımsız.

Yazar Katkıları: Fikir - B.Ö.; Tasarım - B.Ö.; Denetleme - B.Ö., C.K., Ö.V.Ü.; Kaynaklar - B.Ö., C.K.; Malzemeler - B.Ö., C.K.; Veri Toplanması 
ve/veya İşlemesi - B.Ö., C.K.,Ö.V.Ü.; Analiz ve/veya Yorum - B.Ö., C.K., Ö.V.Ü.; Literatür Taraması - B.Ö., C.K.; Yazıyı Yazan - B.Ö., C.K.; Eleştirel inceleme - B.Ö., C.K., Ö.v.Ü.

Çıkar Çatışması: Yazarlar çıkar çatışması bildirmemişlerdir.

Finansal Destek: Yazarlar bu çalışma için finansal destek almadığını belirtmiştir.

\section{REFERENCES}

1. Ammann R, Eckert J. Clinical diagnosis and treatment of echinococcosis in humans. In: Thompson RCA, Lymbery AJ, editors. Echinococcus and hydatid disease. Wallingford: CAB International 1995: 411-63.

2. Placer C, Martin R, Sanchez E, Soleto E. Rupture of abdominal hydatid cysts. Br J Surg 1988; 75: 157. [CrossRef]

3. Sayek I, Onat D. Diagnosis and treatment of uncomplicated hydatid cyst of the liver. World J Surg 2001; 25: 21-7. [CrossRef]

4. Ben Amor N, Gargouri M, Gharbi HA, Ghorbel A, Golvan YJ, Hammou-Jeddi $\mathrm{H}$ et al. Treatment of hepatic hydatid cyst in sheep by echographic puncture. Tunis Med 1986; 64: 325-31.

5. Gharbi HA, Hassine W, Brauner MW, Dupuch K. Ultrasound examination of the hydatic liver. Radiology 1981; 139: 459-63. [CrossRef]

6. Saidi F. Surgery of Hydatid Disease. Philadelphia, Saunders, 1976, pp. 156-281.

7. Sayek I, Yalin R, Sanac Y. Surgical treatment of hydatid disease of the liver. Arch Surg 1980; 115: 847-50. [CrossRef]

8. Prousalidis J, Cosmidis $\mathrm{CH}$, Fahantidis E, Harflaftis N, Aletras $\mathrm{O}$. Surgical treatment of multiple cystic echinococcosis HBP 2004, 6: 110-4.

9. Tekin A, Kücükkartallar T, Kartal A, Kaynak A, Özer Ş, Tavli Ş, et al. Clinical and surgical profile and follow up of patients with liver hydatid cyst from an endemic region. J Gastrointestin Liver Dis 2008; 1: 33-7.

10. Yol S, Kartal A, Tavli S, Sahin M, Vatansev C, Karahan O, et al. Open drainage versus overlapping method in the treatment of hepatic hydatid cyst cavities. Int Surg 1999; 84: 139-43.

11. Akhan O, Ozmen MN, Dincer A, Sayek I, Gocmen A. Liver hydatid disease: long-term results of percutaneous treatment. Radiology 1996; 198: 259-64. [CrossRef]
12. Fayyaz A, Ghani UF. Successful treatment of hydatid cyst of lesser sac with PAIR therapy. J Coll Physicians Surg Pak 2013; 23: 890-2.

13. Smego RA Jr, Bhatti S, Khaliq AA, Beg MA. Percutaneous aspiration injection-reaspiration drainage plus albendazole or mebendazole for hepatic cystic echinococcosis: a meta-analysis. Clin Infect Dis 2003, 37: 1073-83. [CrossRef]

14. Schipper HG, Lameris JS, van Delden OM, Rauws EA, Kager PA. Percutaneous evacuation (PEVAC) of multivesicular echinococcal cysts with or without cystobiliary fistulas which contain non-drainable material: first results of a modified PAIR method. Gut 2002; 50: 718-23. [CrossRef]

15. Buttenshoen K, Carli Buttenshoen D. Echinococcus granulosus infection: the challenge of surgical treatment. Langenbecks Arch Surg 2003; 388: 218-30. [CrossRef]

16. Filice $C$, Brunetti E. Use of PAIR in human cystic chinococcosis. Acta Trop 1997; 64: 95-107. [CrossRef]

17. Pelaez V, Kugler C, Correa D, Del Carpio M, Guangiroli M, Molina $J$, et al. PAIR as percutaneous treatment of hydatid liver cysts. Acta Trop 2000; 75: 197-202. [CrossRef]

18. Avgerinos ED, Pavlakis E, Stathoulopoulos A, Manoukas E, Skarpas $G$, Tsatsoulis $P$, Clinical presentations and surgical management of liver hydatidosis: our 20 year experience. HPB 2006; 8: 189-93. [CrossRef]

19. Akhan O, Dincer A, Gököz A, Sayek I, Havlioglu S, Abbasoglu O, et al. Percutaneous treatment of abdominal hydatid cysts with hypertonic saline and alcohol: an experimental study in sheep. Invest Radiol 1993: 28: 121-7. [CrossRef]

20. Polat KY, Balik AA, Oren D. Percutaneous drainage of hydatid cyst of the liver: long-term results HPB 2002; 4: 163-6. [CrossRef]

21. Lewall DB, McCorkell SJ. Rupture of echinococcal cyst: diagnosis, classification, and clinical implications. AJR 1986; 146: 391-4. [CrossRef]

22. Filice C, Pirola F, Brunetti E, Dughetti S, Strosselli M, Foglieni CS. A new therapeutic approach for hydatid liver cysts. Aspiration and alcohol injection under sonographic guidance. Gastroenterology 1990; 98: 1366-8. [CrossRef]

23. Bean WJ, Rodan BA. Hepatic cysts, treatment with alcohol. AJR 1985; 144: 237-41. [CrossRef] 